\title{
SYSTEM APPROACH IN THE CONSISTENCY CONCEPT AS A WAY OF ORGANISATIONAL ANALYSIS
}

\author{
Iwona Chomiak-Orsa*, Michał Flieger**
}

\begin{abstract}
Background. Organisational excellence is a process that becomes more and more difficult in nowadays' organisations. One of the areas in which this organisational state is built is organisational management nature. When it comes to competitive organisations process management and process organisations are very often introduced. What is very often forgotten is a kind of consistency that must follow process structure implementation and ongoing operations. The problem of consistency is almost not present in this meaning in literature of the subject, so it is a very new approach. To manage in a consistent way organisations need to analyse companies from a static and dynamic perspective. The management of contemporary organisations requires from the managers not only well-established knowledge and wide experience. The problems faced by organisations go beyond the management framework defined in the literature. The organisations are evolving in order to achieve organisational excellence. A key determinant of the improvement of the organisation is to create a coherent management system, which will include all the layers and the perspective of the organisation. Unfortunately, it is extremely difficult to obtain in practice. The identification of these difficulties was the main impetus for the considerations presented in this article.
\end{abstract}

Research aims. The aim of the article is to make a synthesis of the literature devoted to the topic of the consistency of the management structure levels. Unfortunately, the literature in this area is not too abundant, yet. Therefore, the purpose of the study was to identify the main trends of literature in this area and to present an original, synthetic concept to create organisational cohesion.

Methodology. In view of the theoretical nature of the article research methodology consisted on the views of the authors as a result of a literature review. Then the authors were also tempted by several design proposals that are conceptual. The desk research was carried out by studying the literature considering consistency in management and confronting it with the authors' own concepts. Most of the article was developed by using the authors own ideas and in this way it is a new input into management theory.

\footnotetext{
"Wrocław University of Economics. E-mail: iwona.chomiak@ue.wroc.pl
}

** Adam Mickiewicz University in Poznań. E-mail: m.flieger@wp.pl 
Key findings. As the main source of the problem that is described in the article, the authors pointed out the lack of consistency between the planes of management. The pursuit of organisational excellence is a continuous process, which forces the evolutionary nature of the organisation. Thus, the flexible principles of the organisation's functioning in the direction of self-improvement, designing or creating an event organisation may constitute, according to the authors, one of the directions of organisational consistency.

Key words: consistency, process management, consistent management, management structure levels

\section{INTRODUCTION}

When it comes to making the organisation more and more effective the question isstill present on how to become organisationally excellent. There is a number of answers that each expert would give. However, one perspective still seems to be missing - it is theperspective of management consistency. Management in organisations is a complex process. The complexity results from postmodern clients with changeable needs, from rapid environment changes and from competition moves requiring proper adjustments.

In light of the above there comes as no surprise that management system transformation is nowadays a must. New ideas' implementation takes place all the time on each level of management in the organisation and in various areas of business operations. As it concerns all the levels there is a problem of overall planning and coordination, especially from the perspective of strategic management and strategic organisational consistency. Management consistency is a big issue and it still causes problems as there are no proposals how to become consistent and how to master consistency daily. Thus, there appear specific questions which need to be answered by management scientists. The questions are crucial not only for profound understanding of consistency but also for its practical application. This seems to be one of the most important issues for management theory nowadays. Contemporary managers require some specific support as regards the consistency problem, which may be a key to build competitive advantage in a modern way.

Consistency is a universal concept and should be sought in every kind oforganisation. Consistency may be a supportive and necessary step towards innovativeness. When a company is a process one, with modern management concepts implemented and the newest technology 
to attract clients who need innovative products consistency is even more important than in traditional organisations operating in a stable surrounding. The universality of this concept makes it even more important in today's management.

At the same time it is important to introduce the notion of corporate inconsistency. In some way it is the opposite to management consistency and it may be said that wherever there is a lack of consistency inconsistency appears. However, taking this notion to a more detailed level, management inconsistency means the lack of coordination on and between consistency platforms, such as concepts of management, management methods, corporate structure, management style, and human resource characteristics (Flieger, 2016, pp. 21-31).

Taking the above issues into consideration the author of the paper tries to drive attention towards the process of corporate management consistency construction through providing and detailing the corporate consistency concept in management area. Pointing out the corporate consistency concept from the management perspective and its various aspects is one of the main aims of the paper. Managing organisation in the consistency perspective should be present on both dynamic and static level of the organisation.

Modern organisational structures are often connected with processes in organisations (Bober et al., 2004, pp. 25-27). One of the structures that play a more and more important role are process structures, that is why the author concentrated on such structures when considering consistency. Connecting consistency with process structures seems to be very important from a theoretical and practical point of view as there is still a lack of knowledge in this matter. There is a need to provide new solutions for organisations concerning consistency.

In the literature sometimes we find a definition about management system improvement. There are a lot of steps which are characteristic to the improvement process in organisations. The first step is appearing of a new idea in any of the above-mentioned areas. The second step means translating the idea into an organisational concept. The third step is the concept's introduction in practice - creation a new organisation idea, looking for a new group of clients, changing a marketing method, etc. The last step is checking out the outcome of the improvement through control or a satisfaction survey, which forms the base for looking for new solutions or modifying the existing ones (Chomiak-Orsa, \& Flieger, 2011a; 2011b). What is important, all 
the steps require extreme management system flexibility - this way consistency is sustained.

\section{THE THEORY OF THE SYSTEMS AS A BASE OF CONSISTENCY MANAGEMENT}

The consistency theory is based on the concept created by Ludwig von Bertalanffy called the theory of the systems (Robinson, 1974, p. 491). Consistency is connected with the fact that when we change one element of the organisation, we must probably also change other elements to adjust to the change (Bińkowska, 2009, p. 19). This is one of the most important issues mentioned in the theory of the systems. According to system theory, the change of one element of the system influences other elements and hence the functioning of the whole system changes. That is the key for the consistency problem - each change influences consistency in a different way. Thus, each change requires thinking about consistency again and again. This process is represented in Figure 1.

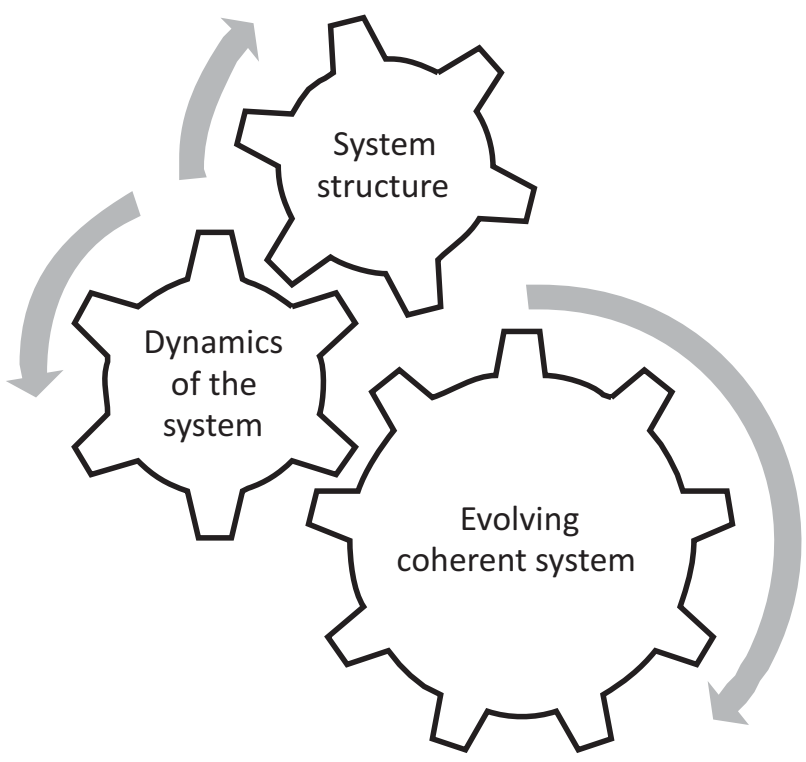

Figure 1. The evolution of the system as a result of changes in static and dynamic part of the system 
When we look at the organisation as at the system (Batko, 2009, pp. 107-116), we optimise the organization by implementing constant changes (as it is in process organisation for example) so we need to see it and analyse it as one system and we need to look in different directions. It means searching for possible effects of changes in various areas of the organisation's functioning. Possible effects may also appear in areas which are located far away from each other.

Understanding the above is a key to move forward. The problems start, when we try to operationalise these assumptions in practice, which means when we try to explain in details what consistency actually means in daily management practice. To be able to define consistency in a way that is helpful to managers, we need to identify the main areas that need to be adjusted and show connections between them. Moreover, we need to show various consistency perspectives, to explain and understand its nature. Thus, we will be able to identify, how possible adjustments influence other areas. This way, the process of harmonisation, adjusting, and consistency building among different organisational areas will be identified, which will allow to implement it in practice. This way the excellence may be approached (Lichtarski, 2004, p. 42).

When we approach corporate management vertically, there is a possibility to see the organisation in the perspective of systems, subsystems, and oversystems. It is known that systems consist of subsystems but in the same time systems are the elements of oversystems. Subsystems may join to create systems and systems join to create oversystems. This perspective may be applied on each management level and in each perspective: dynamic and static. Moreover, all systems are both static and dynamic, which makes it necessary to analyse systems from a static and dynamic point of view. This perspective is represented in Figures 2 and 3.

As we can see in Figure 2, there is a close connection between management levels and system analysis as for the static and dynamic perspective. Each manager, no matter on what management level he operates, needs to search for optimalisation of the system in the perspective of its elements as well as in the perspective of connections between them. First, the consistency building process starts from searching for consistency between elements of analysed management level. The next step is matching the elements vertically through all the management levels. Thus, the static coherency is obtained in the whole 
system. However, at the same time managers must remember about the dynamic nature of elements' connections and dynamic consistency as a result of dynamic analysis. As we can see the consistency building process is quite complex and requires managers thinking in different directions at the same time.

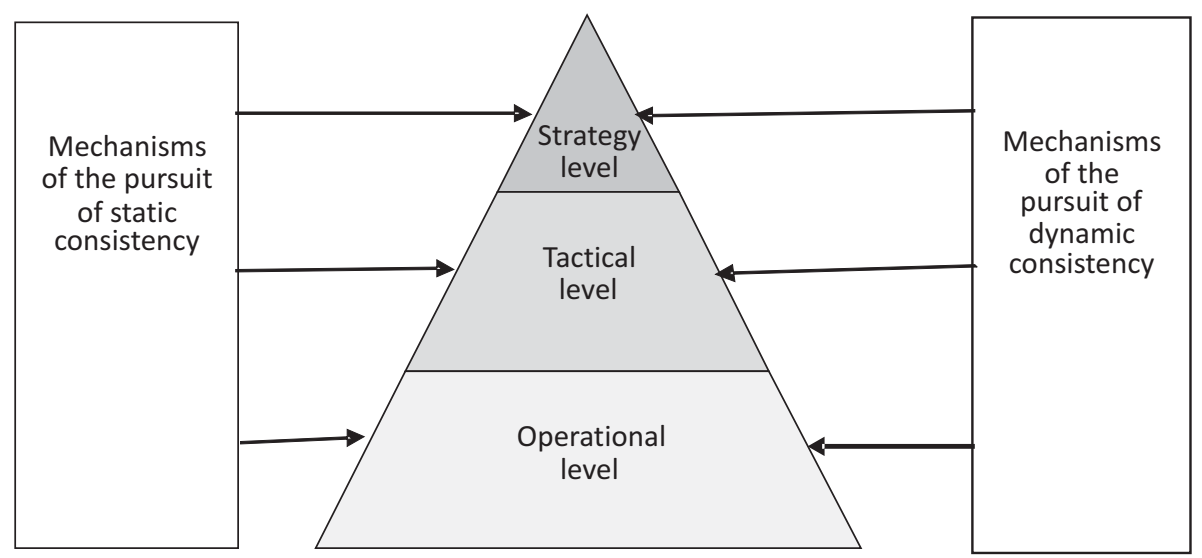

Figure 2. Static and dynamic perspective to create organisational cohesion Source: own work.

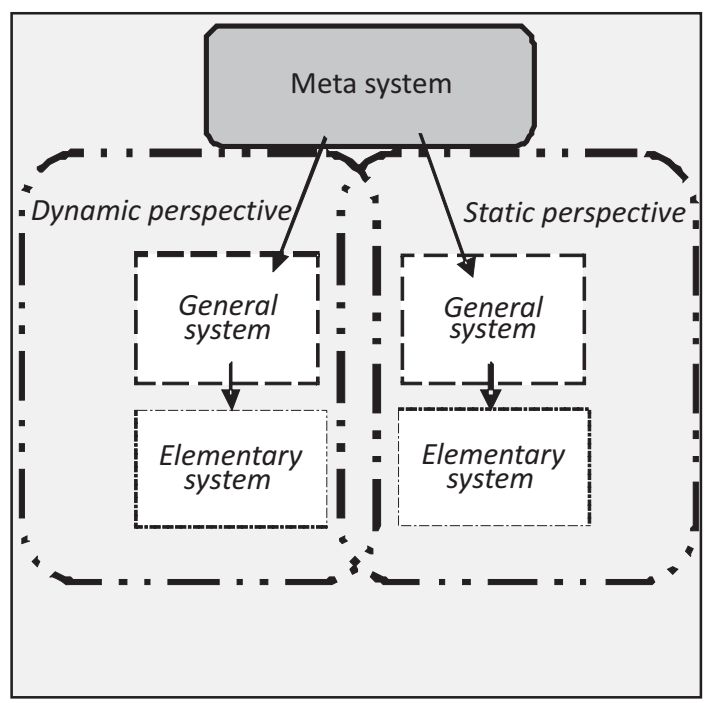

Figure 3. Architecture of the analytic system creating organisational cohesion Source: own work. 
As we can see in Figure 3, the consistency problem needs to be approached also from the perspective of system, oversystem, and subsystem analysis. However, this perspective needs to be put at the perspective of the dynamic and static analysis on each level of management, which makes the consistency problem even more complex. This way, however, it is possible to approach consistency starting from smaller elements, which are usually easier to analyse, and then moving up to higher levels of analysis comprehending bigger elements. So, for instance the analysis may be started from system static analysis on the operational level, then moving to the tactical and strategic level and then (or at the same time) on the same path, but with a dynamic analysis. Such approach makes it possible that we do not forget about any elements that need to be planned and verified when searching system consistency.

\section{CORPORATE CONSISTENCY IN MANAGEMENT}

Thinking about management consistency and the way the consistency may be achieved, it is crucial to remember that the main direction is always shown by the mission, vision, strategy, and strategic goals. Since each organisation has a different strategic level the construction of the internal shape of consistency platforms will be different in each case and appropriately adjusted. This approach is necessary and has one big advantage, which is the need to reflect on strategic issues first, before further decisions on consistency are made. This logic shows that there is no consistency without strategic assumptions.

\subsection{Consistency of management levels}

To explain and understand management consistency, there is a need to operationalise the levels of analysis. Consistency platforms are proposed to make the analysis possible on each management level. In this way managers see clearly what organisational elements to analyse and where the consistency is needed.

In management consistency proposed in the paper there are three consistency platforms which may be effectively considered by managers. Each of them should create a consistent system, which naturally influences organisational effectiveness and competitiveness. 
What we should start with is a conceptual level, which consists of concepts and methods of management (Jabłoński, 2002, pp. 95-97). Introducing a given concept triggers the need to introduce other concepts, so that the first one is complementary supported. When there is knowledge about the methods and concepts among managers, some of the elements that are complementary are quite often easy to spot. However, a fully consistent system will need a major analysis. This kind of analysis makes it possible to move towards the next level.

Level two consists of two key elements. The first one is the organisational structure that may be divided into a static and dynamic structure. The static one is a functional structure and the dynamic one is a process one. Generally speaking, organisational structures may be functional structures, process structures (and process-like structures, e.g. virtual), and also hybrid structures which join functional and process ones. Each of the listed kinds of structures differs in its functioning and requires adjusting the management style and recognising mechanisms which are natural for the structure. When the mechanisms are recognised and understood for the organization, they must be used actively by managers of all company levels (Flieger, 2007, pp. 36-37).

The last level of management is the executive one, which integrates the previously analysed platforms with human resource management and other non-material resources. This platform says that human resources of the company and other non-material resources must be adjusted to consistent systems of concepts and methods of management and to the organisational structure and to the style and mechanisms of management. The human capital of the organisation must have some characteristics which are matched to the requirements resulting from the previous platforms. The above has been presented in Figure 4.

As we can see in Figure 4, there three possible levels of analysis have been represented, but in practice managers may add their own levels and perspectives in which they think they should look for organisational consistency. 


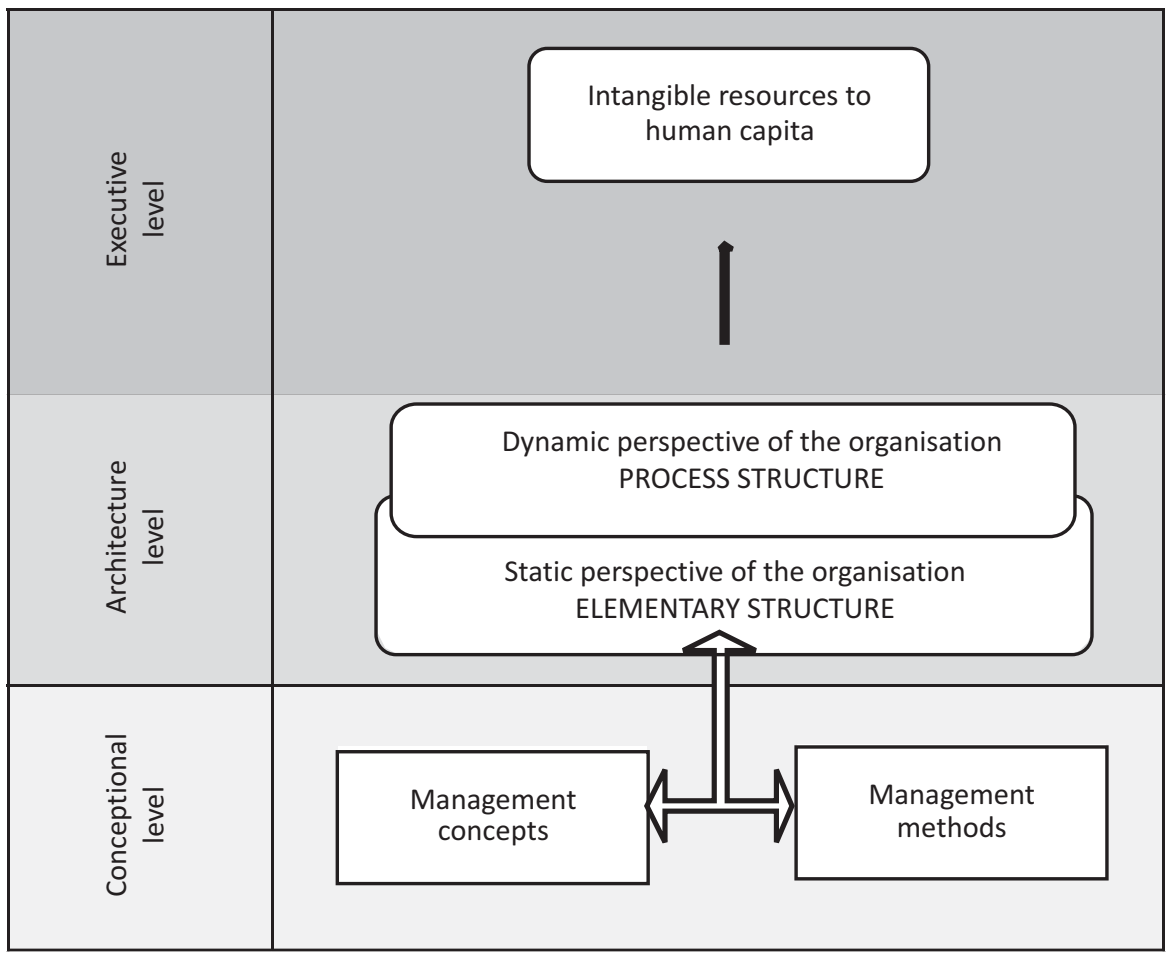

Figure 4. The concept of consistency management levels

Source: own work.

\subsection{Consistency in process organisations - structure and goals perspective}

Process organisations have their own specificity and that is why consistency needs to be verified accordingly. There are four levels of process architecture in each organisation. The first one is the strategic level, which consists of the main and support processes (Bitkowska, 2009,pp. 131-132). Here, the list of processes present in an organisation is presented with specific names of the processes. When we are interested if a process consists of sub-processes, we need to move onto the lower level of process structure which shows specific sub-processes forming processes from the strategic level. The third level of the process structure is a level which shows sub-processes - the way they are constructed. Here we see specific process operations in a given order with process nodes responsible for each operation. The last level of 
process architecture is the configuration of a given process node which shows how the operations are performed. Here we can see procedures and instructions for given process operations.

As we can see in Figure 5,we can also approach the consistency in process organisations from the point of view of the influence processes have on one another. On the strategic level processes have a key meaning because they determine processes on the tactic level. Tactic level processes are realised by operational processes. This way, when we approach the structure from this point of view, there is a need for such structure to be consistent, because only consistency in this meaning may result in organisational effectiveness (Jon, 2001, p. 50).

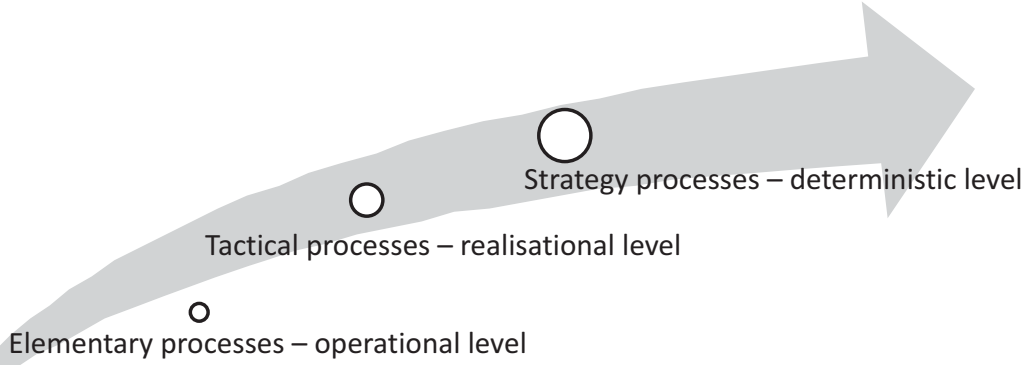

Figure 5. The process of organisational development in the direction of consistency management levels

Source: own work.

\subsection{Goals consistency}

Taking into consideration process consistency, we must remember that each process has its own goal. Such goals need to be consistent, so that each goal supports other goals. In hybrid structures, consistency concerns consistency between functional and process goals. The main profits of goals consistency in organisations are:

a. Compatibility of proposed solutions - similar goals lead to coherent solutions implemented in the organisation.

b. Unique methods of human resource management - specific goals require specific people to reach them. Thus, methods to manage people need to be unique and specific for organisations. 
c. Business process standardisation-coherent goals as for vertical and process structures allow organisations for process standardisation as the goals are less likely to be changed rapidly.

d. Effective communication - goals consistency results in better understanding between system elements in the organisation, which influences better information flow.

Getting into goals consistency deeper, we may differentiate two points of view considering the consistency analysis. As stated above, in hybrid organisations there is a question on how to build a consistent system of organisational goals. The problem is that functions and functional workers have their own goals but at the same time they are part of processes where they form process nodes with other goals. Thus, there is a need to coordinate the workers' goals (functional and process) and goals of functions and processes. The difficulty here lies in the number of goals that need to be coordinated. It is a complex task to analyse and coordinate the goals but at the same time it is necessary because only then do the workers go in the same direction realising their functional and process goals.

The other point of view as for goals consistency is adjusting process goals with strategic goals of the company. Having a lot of processes at the same time and concentrating on their optimising it may be difficult to see the strategic level. Processes are not separate beings in the organisation and even when they work perfectly there is a question if they are incorporated in company strategy. Such perspective gives another platform of consistency analysis for managers in any organisation and should influence managers' decisions accordingly.

\section{CONCLUSIONS}

When we consider the problem of organisational excellence, it is not easy to answer the question on how to achieve this state of perfect operations. Of course this is an ideal model, however it shows the direction in which managers should lead their organisations.

In order to understand and implement organisational excellence there is a need to operationalise it somehow. First of all, management takes place on different organisational levels. Secondly, organisational optimalisation concerns the dynamic as well as the static perspective. Last, on each level and in each perspective there are systems and 
subsystems that need to be coordinated to be consistent. In this way it may be possible for managers to understand and implement consistency in practice.

Consistency can be reached by looking into the organisation through specific perspectives called consistency platforms and perspectives. Building consistency requires focusing on each platform separately and then, according to the theory of the systems, matching platforms to one another. This way a profound analysis is possible and managers eliminate the risk of missing important areas which need to be harmonised.

In process organisations it is possible to pinpoint specific analysis perspectives, which are of a huge practical importance to managers. Analysing organisations through such perspectives enables them to improve the organisation step by step and at the same time all the decisions and improvements are coherent. It is a very big advantage of the consistency concept because in this way strategic goals of the company are reached effectively.

However, the problem in management literature is that there are no specific tools to measure consistency. Also consistency awareness among managers as well as in the literature almost does not exist. Thus, there is a need to develop the topic in a theoretical sphere as well as broaden managers' knowledge in practice. There still seems to be a lot to be accomplished and that is a challenge which management scientists need to meet.

The consistency theory is a new concept and it brings a new management perspective to the management of contemporary organisations. The concept searches for consistency platforms and points out possible perspectives from which managers should analyse their organisations to look for better efficiency and competitive advantage. As the concept is in its initial phase it needs more and more research to develop and to be of practical use for managers.

\section{REFERENCES}

Batko, R. (2009). Zarzqdzanie jakościq w urzędach gminy. Kraków: Wydawnictwo Uniwersytetu Jagiellońskiego.

Bińkowska, A. (2009). Zarzqdzanie procesami biznesowymi w przedsiębiorstwie. Warszawa: Vizja Press.

Bober, J., Mazur, S., Turowski, B., \& Zawicki, M. (2004). Rozwój instytucjonalny. Kraków: Małopolska Szkoła Administracji Publicznej w Krakowie. 
Bober, J., Turowski, B., Zawicki, M., \& Mazur, S. (2009). Analiza instytucjonalna urzędu gminy. Kraków: Małopolska Szkoła Administracji Publicznej Akademii Ekonomicznej w Krakowie.

Cellary, W. (2011). Innowacyjność $i$ nauka to nie to samo czyli jakiej innowacyjności potrzeba $w$ Polsce?, Konferencja inaugurująca projekt „Przedsiębiorczy doktorant - inwestycja w innowacyjny rozwój regionu”, Wrocław.

Chomiak-Orsa, I., \& Flieger, M. (2011a). Computerization as the Improvement of Processes in Local Governments. In: J. Korczak (ed.), Advanced Information Technologies for Management. Zeszyty Naukowe Uniwersytetu Ekonomicznego we Wrocławiu, Wrocław.

Chomiak-Orsa, I., \& Flieger, M. (2011b). Inżynieria procesów zarzadzania na przykładzie wybranych gmin w Wielkopolsce. In : J. Gołuchowski (ed.), Studia Ekonomiczne. Zeszyty Naukowe Uniwersytetu Ekonomicznego w Katowicach, seria Studia Ekonomiczne, Katowice, pp. 37-38.

Chomiak-Orsa, I., \& Flieger, M. (2011c). Evaluation methods in effective ICT projects implementation. In: L. Maciaszek L. (ed.), Business Informatics. Zeszyty Naukowe Uniwersytetu Ekonomicznego we Wrocławiu, Wrocław.

Flieger, M. (2016). Koncepcja spójności organizacyjnej. Organizacja i Zarzadzanie, 2(34). Gliwice: Wydawnictwo Politechniki Ślaskiej.

Flieger, M. (2007). Od administrowania do zarządzania publicznego - transformacja stanowiąca warunek efektywnego zarządzania gminą oraz przedsiębiorstwami sektora publicznego. Prace Naukowe Akademii Ekonomicznej we Wrocławiu, 1184. Wrocław: Wyd. Akademii Ekonomicznej.

Jabłoński, A. (2002). Anglosaska koncepcja nowej administracji publicznej. In: A Ferens, I. Macek (eds.), Administracja i polityka: administracja publiczna w procesie przemian. Wrocław: Wydawnictwo Uniwersytetu Wrocławskiego. Jon, P. (2001). Local Governance in Western Europe. London: SAGE Publications. Leksykon zarzadzania (2004). Warszawa: Difin.

Lichtarski, J. (2004). O relacji między podejściem funkcjonalnym i procesowym w zarządzaniu. In: M. Romabowska, M. Trocki (eds.), Podejście procesowe w zarzadzaniu, t. 1. Warszawa: AGH.

Nowak, J. (2006). Modernizacja lokalnej administracji publicznej a rozwój lokalny. Poznań: Wydawnictwo Akademii Ekonomicznej w Poznaniu.

Perechuda, K. (2000). Zarzadzanie przedsiębiorstwem przyszłości. Warszawa: Agencja Wydawnicza Placet.

Robinson, S. (1974). Stability Theory for Systems of Inequalities. SIAM Journal, 13/4. Auckland.

Stiglitz, J. (2004). Ekonomia sektora publicznego. Warszawa: PWN. 


\title{
PODEJŚCIE SYSTEMOWE W KONCEPCJI SPÓJNOŚCI JAKO SPOSÓB ANALIZY ORGANIZACYJNEJ
}

\begin{abstract}
Abstrakt
Tło badań. Doskonałość organizacyjna jest procesem, który staje się coraz bardziej trudny w czasach współczesnych. Jeden obszar, w którym ten stan organizacji został zbudowany, to obszar natury organizacyjnej zarządzania. Gdy chodzi o konkurencyjność organizacji procesu zarządzania i organizacji procesu, często zapomina się, co jest swego rodzaju spójnościa, która musi dotyczyć struktury procesu, bieżących operacji oraz innych obszarów działania organizacji. Problem spójności prawie nie jest obecny w tym sensie w literaturze przedmiotu, więc jest to nowe podejście. Do zarządzania w organizacjach w spójny sposób trzeba analizować firmy z perspektyw statycznej i dynamicznej. Zarządzanie współczesnymi organizacjami wymaga od managerów nie tylko ugruntowanej wiedzy, ale i szerokiego doświadczenia. Problemy, z jakimi borykaja się organizacje, wykraczaja poza definiowane w literaturze ramy zarządzania. Organizacje ewoluuja, dążąc do osiagania doskonałości organizacyjnej. Istotną determinantą doskonalenia organizacji jest tworzenie spójnych systemów zarządzania, które będą obejmowały wszystkie warstwy oraz perspektywy organizacji. Niestety w praktyce jest to niezmiernie trudne do uzyskania. Identyfikacja tych trudności stanowiła główny bodziec dla podjęcia rozważań zaprezentowanych $\mathrm{w}$ niniejszym artykule.
\end{abstract}

Cele badań. Celem artykułu jest dokonanie syntezy literatury poświęconej zagadnieniu spójności poziomów zarządzania. Niestety piśmiennictwo w tym obszarze nie jest jeszcze zbyt bogate. Toteż celem badań było rozpoznanie głównych trendów literaturowych w tym obszarze oraz zaprezentowanie własnej, syntetycznej koncepcji tworzenia spójności organizacyjnej.

Metodologia. Z uwagi na teoretyczny charakter artykułu, zastosowana metodyka badań polegała na sformułowaniu poglądów autorów w wyniku dokonanego przeglądu literatury. Następnie autorzy pokusili się o kilka projektujących wniosków, które maja charakter koncepcyjny.

Kluczowe wnioski. Jako główne źródło problemu opisanego w artykule autorzy wskazali brak spójności między płaszczyznami zarządzania. Dążenie do doskonałości organizacyjnej jest procesem ciagłym, który wymusza ewolucyjny charakter organizacji. Toteż uelastycznianie zasad funkcjonowania organizacji w kierunku samodoskonalenia, samoprojektowania czy tworzenia organizacji eventowych może stanowić - zdaniem autorów - jeden z kierunków uzyskania spójności organizacyjnej.

Słowa kluczowe: spójność, procesy zarządzania, spójność zarządzania, płaszczyzny zarządzania 